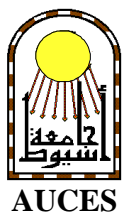

\title{
GEOPHYSICAL AND HYDROGEOLOGICAL TOOLS FOR GROUNDWATER EXPLORATION AND EVALUATION IN THE AREA AROUND IDFU-MARSA ALAM ROAD EASTERN DESERT, EGYPT
}

\author{
Abdel hay A. Farrag ${ }^{*}$, H. A. Ibrahim ${ }^{* *}$, A.H. El-Hussaini ${ }^{* *}$ and A.A. Abdel Kader ${ }^{* * *}$ \\ *Assistant Professor, **Professor and ***Assistant lecturer \\ Department of Geology, Faculty of Science, Assiut University
}

\begin{abstract}
:
Idfu-Marsa Alam Road traversing the southern part of the Egyptian Eastern Desert, between the latitudes $24^{\circ} 00^{\prime}$ and $25^{\circ} 05^{\prime} \mathrm{N}$ and longitudes $33^{\circ} 00^{\prime}$ and $35^{\circ} 00^{\prime} \mathrm{E}$. The areas surrounding the road is almost of desert condition and dry climate. The groundwater in the area is of great importance where it is the unique source for drinking and grazing water.

The groundwater exploration and evaluation in the mentioned area are the main objective of the present study. Some localities were carefully selected for applying the geophysical and the hydrogeological techniques to achive the gaol of the study. Both the direct current resistivity and the shallow seismic refraction methods were applied. Twenty four vertical electrical sounding stations were measured and six seismic refraction spreads were done. The collected climatic data and the hydrogeological information were analyzed and evaluated using the available software.

Three main groundwater aquifers were detected and distinguished in the area. The groundwaters in these aquifers are generally present under unconfined conditions. The water compositions are mainly related to their bearing rocks. In few localities the groundwater can be used for domestic and irrigation purposes. The study cleared also that Wadi Abbad and Wadi El Shaghab are the best localities suggested for drilling groundwater wells. The application of these results is very important for developing the area.
\end{abstract}

\section{INTRODUCTION:}

Over the past five decades in Egypt, the population densities increased and concentrated in the Nile Valley. The adjacent vast desert areas represent the unique solution over which the population and the economic activities can be redistributed. The reclamation of such areas depends mainly on the occurance, quantity and quality of the groundwater. So, intensive studies are needed to explore new groundwater aquifers and strategies must be suggested to use this water source after its evaluation.
The study area represents a part of an arid region in which the groundwater recharge is controlled by the prevailing meteorological and geomorphological conditions. The physical properties of the water-bearings in addition to the geological structures play an important role in the groundwater occurrence and regime.

Few individual geological, geophysical and hydrogeological studies were carried out on the area. Dealing with the geology of the area some regional and local studies were done, from which the works of El Ramly et.al (1960), El 
shazly (1964), Akaad et.al (1969), Akaad et. al (1980), Ward et. al (1979), Yousef (1984) and Mohran (1990). Some previous distributed geophysical studies were carried from these studies the works of Khaled (1995). Limited hydrogeological studies were carried out from then the works of Abdel Mogheeth et. al (1988), Misak et. al (1990) and Attia (1999).

The present study focuses on the hydrogeological conditions and on the water situation and characters in the various water bearing formation in the area. The detection of new water resources in such dry desert areas is of great importance. Geophysical methods especially the geoelectric and shallow seismic refraction methods have been used routinely for groundwater exploration. The two methods were applied, the electrical method represented by the direct current resistivity (D.C.) and the seismic methods represented by the shallow seismic refraction methods. Some representative localities have been chosen in the area according to their geological and geomorphological situations to apply these geophysical tools for groundwater investigation and exploration. The results of the application of these methods are used to delineate a favorable hydrogeophysical regime for productive aquifers in the area.

\section{Study Site:}

The study area is extending from Idfu on the Nile Valley to Marsa Alam on the Red Sea (Fig.1).

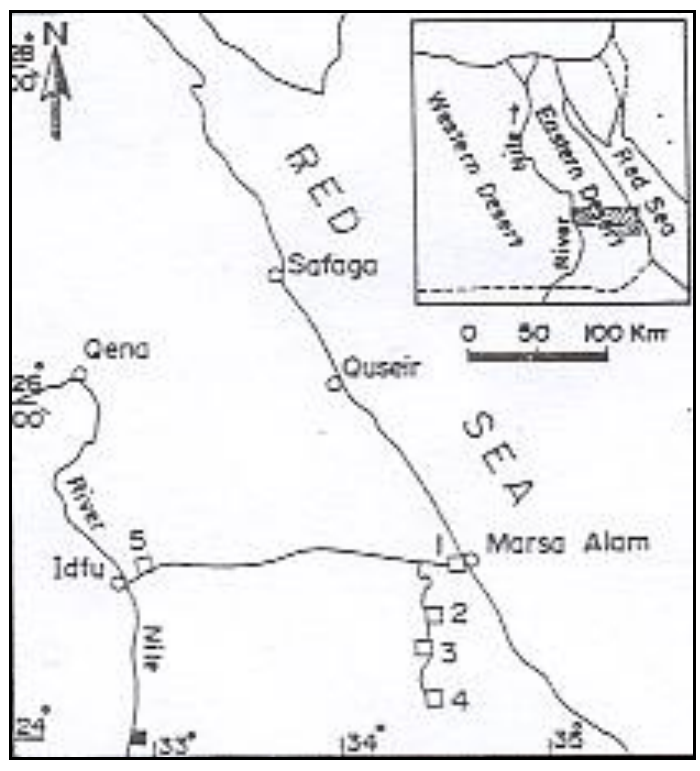

(a)

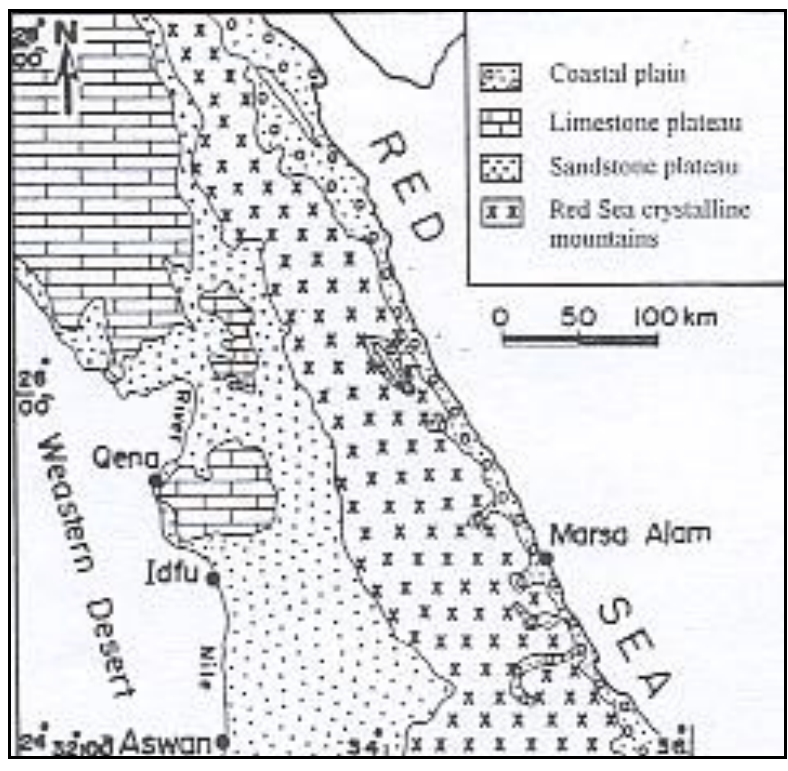

(b)

Fig.(1):

(a) Location map and (b) main geological and morphological units of Idfu Marsa-Alam area, after El Shamy 1992 
The area is mainly occupied by igneous and metamorphic rocks of the Pre-Cambrian Basement Complex of Egypt. To the west, the Basement Complex is overlained unconformably by the Nubian Sandstone of the Upper Cretaceous age, while to the east on the Red Sea coast the Basement Complex is overlained by coastal sediments of Miocene to Recent ages. The area lies within the arid belt of Egypt. Climatically, the area is dominated by long hot summers and short warm winters, low rainfall and high evaporation rates. The mean annual rainfall is about $5 \mathrm{~mm}$. Most of the rainfalls occur on the coastal area during the winter seasons (October to December). The average maximum temperatures is ranging from $25^{\circ}$ to $37 \mathrm{C}^{\mathbf{o}}$.

The groundwater in the area is recharged from the limited occasional rainfalls and tolerant floods, which take place on the mountainous areas and on the sedimentary hills. through the wadies or through the fractured rocks. A limited amount of this water is kept in the catchment areas including the granular rocks and the adjacent fractured and wethered basement rocks.

The population in the area is still very limited and the agricultural activities are almost negligible. However, limited quantities of water are currently pumped from the hand dug wells which are distributed in the area.

\section{METHODS AND TOOLS:}

Some representative localities have been selected to apply the electric resistivity and the sesimic refraction methods. These are; a) Wadi Abbad and Wadi El-Shaghab in the Nubian Sandstone plateau. B) Wadi Hafafit, Wadi Natash and Wadi El-Shiekh El-Shazly in the mountainous area and, c) Wadi Alam in the coastal plain (Fig. 2).

Most rainfalls are drained out of the area

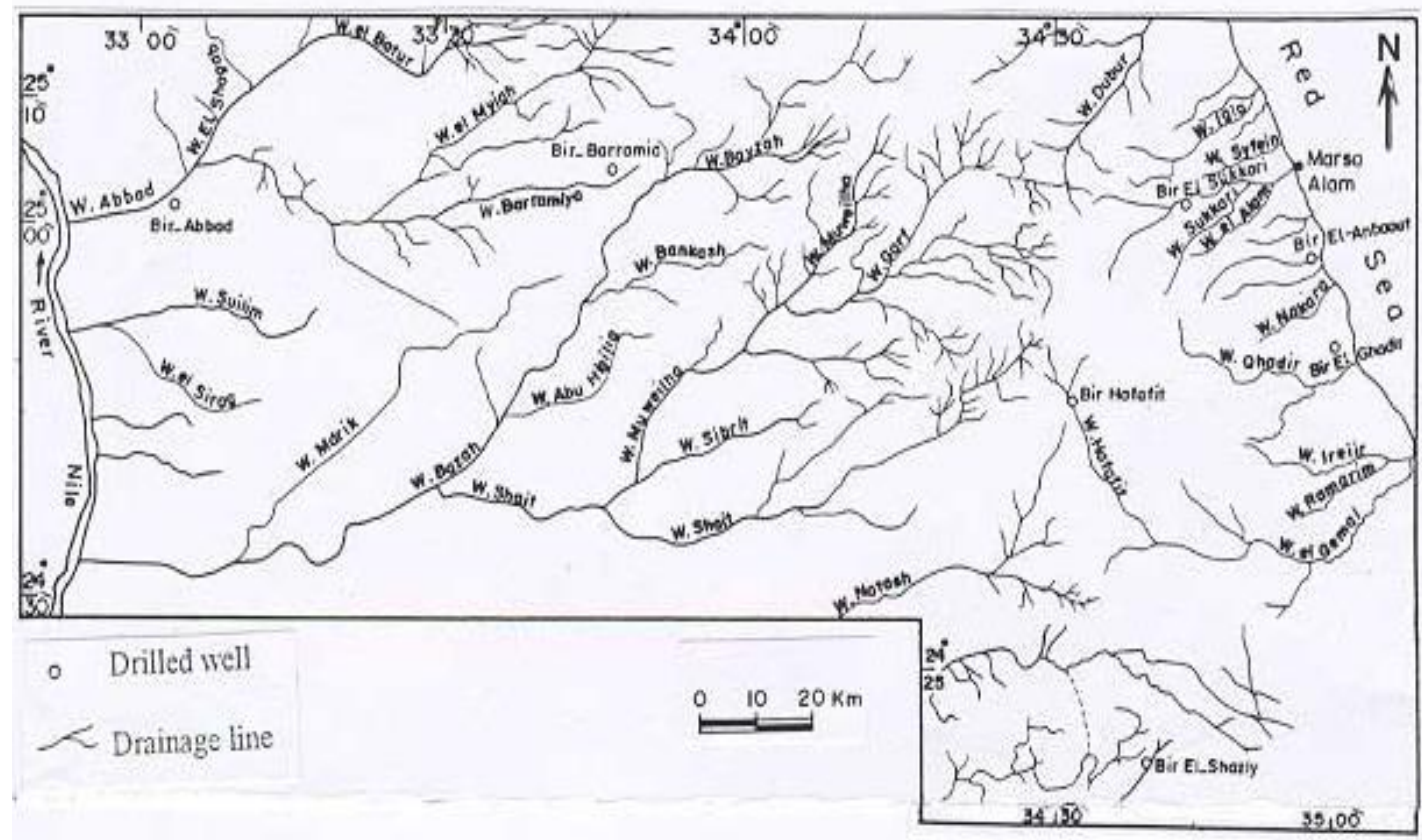

Fig. (2): The main wadies and wells in Idfu-Marsa Alam area. 


\section{A-Field Observations, Measurements and Techniques:}

Electrical resistivity measurements were carried-out using ABEM-AC Terrameter SAS equipment. Direct current resistivity involved vertical electrical sounding (VES), using Schlumberger electrode array. Twenty four VES-stations were measured where the current electrode spacing $(\mathrm{AB} / 2)$ varied from 1.5 to 600 $m$ depending on the topographic accessibility in the surveyed areas.

Shallow seismic refraction measurements were carried out in order to determine the depth to the basement rocks. Seismic refraction measurements were made using a multichannel enhancement seismograph model ES-1225. Six seismic refraction spreads were completed. The length of each spread depended on the topographic accessibility. The geophones numbers and the spreads lengths were varied according to the topographic features and the expected depth to the basement rocks. Symmetrical pairs of shots were fired into spreads with geophone placed at $20 \mathrm{~m}$ intervals at Wadi Alam, Wadi El-Shaghab and Wadi Abbad and $10 \mathrm{~m}$ intervals at the mountainous areas.

The groundwater depths have been measured in selected wells by the use of electric sounder with $100 \mathrm{~m}$ wire and probe. The accurate coordinates of the different wells were determined by using the geographic position system (GPS) technique.

17 groundwater samples were collected from eight wells, some of them were periodically collected to show the variation in the groundwater chemistry with time. The electrical conductivity (EC), the total dissolved solids (TDS) and the hydrogen ion concentrations (pH) were measured in the field by the Oyster pH/conductivity and TDS meter.

\section{B-Laboratory Analysis and Interpretations:}

The measured sounding curves were distinguished into two groups, according to their penetrating depth. The first group included those VES-stations in which the depth to the basement rocks is relatively small (Hafafit, Natash and El-Shazly area). Those curves are representing three and four layers. The second group of curves are those carried for areas in which the depth to basement rocks is reletivly high (Wadi Alam and Wadi ElShaghab).

The apparent resistivity values were represented in terms of apparent resistivity sections. The measured data were quantitatively interpretated to determine the thicknesses and true resistivities of the different geoelectric formations. The interpretation techniques were carried manually using matching curves (Orellana $e t$. al, 1966) and automatically using Zohdy 1989 and Velpen 1988, methods. The resultant VES-curves were adjusted and the multilayered models were transformed and reduced to layered models. The results of the VESes measured near the drilled wells were correlated with the drilling data.

The seismic measurements were plotted on distance versus time and introduced into computer for interpretation. Two types of software were used for interpretation. SEISVEW program (Timothy et.al,1987) was used for interpretation mountainous region data where the depth to the basement rocks is expected to be small the length of spread was $240 \mathrm{~m}$, and the numbers of geophones were 24 . SIPT program was applied for interpretation the measured data of the areas in which depth to the bed rocks is the expected to be long as it is in Wadi Alam, Wadi Abbad and Wadi ElShaghab. In that case the data were measured 
with long spreads, and the number of geophones was 36 with $20 \mathrm{~m}$ interval.

The chemical analyses of the collected water samples were carried out in the Soil and Water Laboratory of the Agriculture College in Assiut University. The sodium adsorption ratio (SAR) values of each water sample were calculated by using Richard, 1954 equation:

$$
S A R=\frac{N a^{+1}}{\frac{1}{2} \sqrt{C a^{+2}+M g^{+2}}}
$$

The total hardness (TH) in ppm and the sodium percentage $(\mathrm{Na} \%)$ values were determined using the equations Tood 1959);

$$
\begin{gathered}
\mathrm{T} \mathrm{H}=2.497 \mathrm{Ca}+4.115 \mathrm{Mg} \\
\mathrm{Na} \%=\frac{(\mathrm{Na}+\mathrm{K}) 100}{\mathrm{Ca}+\mathrm{Mg}+\mathrm{Na}+\mathrm{k}} \quad(\text { epm })
\end{gathered}
$$

The trilinear method of plotting (Piper, 1953), has been used to understand problems about the geochemical evaluation of the groundwater.

\section{RESULTS AND DISCUSSION:}

\section{A-The Groundwater Situation and Aquifers:}

The groundwater in the study areas is detected in some geological formations having different ages and characters. These formations can be grouped into three main hydrogeological units; 1)The Nubian sandstone unit. 2)The Red Sea mountainous unit, and 3)The coastal zone unit. The groundwater depths and salinities in addition to the aquifers types in each hydrogeolgical unit are summarized in Table (1). The groundwater situations in each

\begin{tabular}{|c|c|c|c|c|c|c|}
\hline Water points & Location & $\begin{array}{l}\text { Meanwater } \\
\text { depth } m\end{array}$ & Aquifer Type & $\begin{array}{c}\text { Hydrogeologiocal } \\
\text { unit }\end{array}$ & $\begin{array}{l}\text { Water } \\
\text { supply }\end{array}$ & $\begin{array}{c}\text { Water } \\
\text { salinity }\end{array}$ \\
\hline Nile Water & $\begin{array}{lr}5^{\circ} & 03^{\prime} \mathbf{N} \\
32^{\circ} & 50 \\
\end{array}$ & Canal & Surface water & Surface & & Good \\
\hline Abbad (1) & 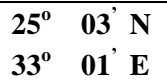 & 3 & Unconfined & $\begin{array}{c}\text { Nubia } \\
\text { Sandstone }\end{array}$ & $\begin{array}{l}\text { Aboundant } \\
\text { Supply }\end{array}$ & $\begin{array}{c}\text { Slightly } \\
\text { Brachish }\end{array}$ \\
\hline Barramia (2) & $\begin{array}{lll}2^{0} & 0^{\prime} & \mathrm{N} \\
3^{\mathrm{o}} & 47^{\prime} & \mathrm{E}\end{array}$ & 31 & $\begin{array}{l}\text { Fracture } \\
\text { Rhyolite }\end{array}$ & Mountainous & $\begin{array}{c}\text { Large } \\
\text { Supply }\end{array}$ & Good \\
\hline Hafafit (3) & $\begin{array}{ll}24^{\circ} & 45^{\prime} \mathrm{N} \\
34^{\circ} & 31^{\prime} \mathrm{E}\end{array}$ & 21.4 & $\begin{array}{c}\text { Fracture } \\
\text { Metasedioments }\end{array}$ & Mountainous & Scanty & Brakish \\
\hline El-Shazly (4) & $\begin{array}{ll}24^{\circ} & 12^{\prime}, \mathrm{N} \\
34^{\circ} & 38^{\prime} \mathrm{E}\end{array}$ & 4 & $\begin{array}{c}\text { Fracture } \\
\text { Metavolcanic }\end{array}$ & Mountainous & $\begin{array}{c}\text { Poor } \\
\text { Inconstant }\end{array}$ & Brakish \\
\hline Sukkary (5) & $\begin{array}{lll}25^{\circ} & 02^{\prime} & \mathrm{N} \\
34^{\circ} & 43^{\prime} & \mathrm{E}\end{array}$ & 13.4 & $\begin{array}{c}\text { Fracture } \\
\text { Metavolcanic }\end{array}$ & Mountainous & $\begin{array}{l}12 \mathrm{~m}^{3} / \text { day } \\
\text { Discharge }\end{array}$ & $\begin{array}{l}\text { Slightly } \\
\text { Brakish }\end{array}$ \\
\hline Igli (6) & $\begin{array}{lll}25^{\circ} & 07^{\prime} & \mathrm{N} \\
34^{\circ} & 45^{\prime} & \mathrm{E}\end{array}$ & 7.5 & $\begin{array}{c}\text { Fracture } \\
\text { Hammamat }\end{array}$ & Mountainous & Scanty & Good \\
\hline Anbaout (7) & $\begin{array}{ll}24^{0} & 51^{\prime} \mathrm{N} \\
34^{\circ} & 49^{\prime} \mathrm{E}\end{array}$ & 2.5 & $\begin{array}{c}\text { Alluvial } \\
\text { Deposits }\end{array}$ & Coastal & Unknown & Brakish \\
\hline Ghadeir (8) & $\begin{array}{lll}24^{\circ} & 49^{\prime} & \mathrm{N} \\
34^{\circ} & 59^{\prime} & \mathrm{E}\end{array}$ & 4.5 & $\begin{array}{c}\text { Alluvial } \\
\text { Deposits }\end{array}$ & Coastal & Unknown & Brakish \\
\hline
\end{tabular}
hydrogelogical unit are described briefly here.

Table (1):The selected water points represent the main aquifer in each hydrogeological unit in Idfu-Marsa Alam area 


\section{1-The Nubian Sandstone Unit:}

The Nubian Sandstone rocks of Upper Cretaceous age represents the oldest porous sedimentary units overlying unconformably the basement rocks in the Eastern Desert. The main recharging sources of the groundwater there are rainfalls, flash floods, and the groundwater flowing from the high mountainous belt at the eastern and southern sides. The water is discharged to the lower aquifers, or by direct evaporation from the groundwater.

In the Nubian Sandstone plateau (Wadi Abbad and Wadi El-Shaghab) the subsurface geoelectric cross-sections (Fig. 3) show that, the surface zone which is composed of dry sands and gravels having high resistivities values ranging between 1000 and 4000 Ohm.m. The thickness of this zone ranges from $5 \mathrm{~m}$ at the wadies sides to $15 \mathrm{~m}$ at the main coarses of the wadies. The second geoelectic layer has resistivity values less than 200 Ohm.m and thickness ranges from 20 to $60 \mathrm{~m}$ at the main stream of the wadies. This layer is considered the main water-bearing layer in the Nubian sandstone. The resistivity of the third layer is more than $1000 \mathrm{Ohm} . \mathrm{m}$. it may be composed of massive rock materials (Nubian Sandstones).

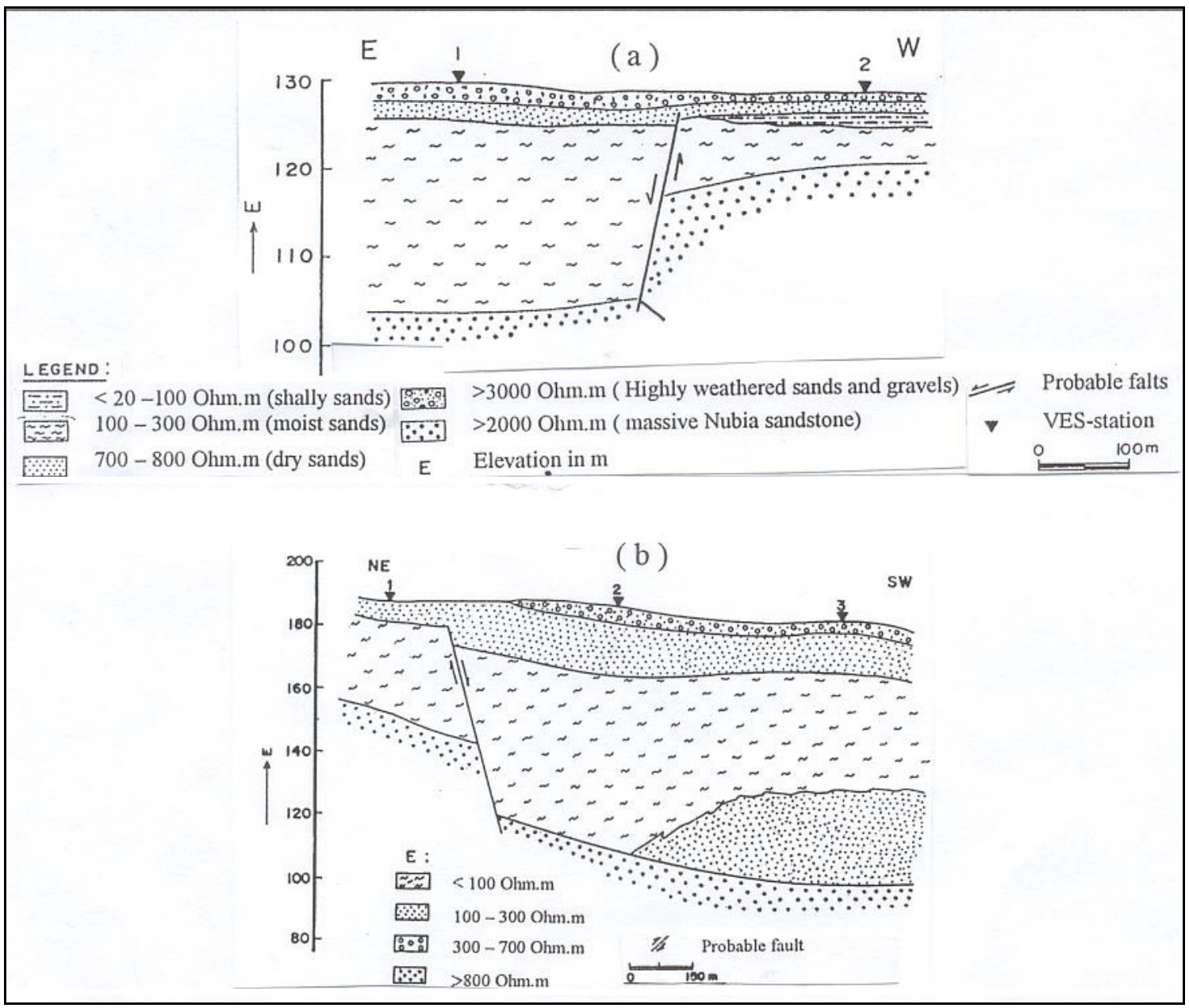

Fig.(3): Geoelectrical cross-sections in the Nubian Sandstone plateau (a in Wadi Abbad and $\underline{b}$ in Wadi El Shaghab) 
Four geoseismic layers were distinguished from the seismic data measured on the Nubian Sandstone plateau (Wadi Abbad and Wadi ElShaghab) (Fig. 4). The top layer velocity was less than $900 \mathrm{~m} / \mathrm{s}$ and its thickness ranged from 1 to $10 \mathrm{~m}$. The average thickness of the second layer was $45 \mathrm{~m}$ in which the velocities ranged from 1300 to $2000 \mathrm{~m} / \mathrm{s}$. In the third layer the seismic velocity was about $2800 \mathrm{~m} / \mathrm{s}$ and its thickness ranged between 44 and $114 \mathrm{~m}$. It is underlaind by rocks having high seismic velocity $(4000$ to $4300 \mathrm{~m} / \mathrm{s})$.

According to present geophysical investigation and the previous geological studies two water-bearing zones can be identified in the Nubian Sandstone plateau:
i-The lower aquifer which is composed of medium to coarse grained sandstones is overlying unconformably the basement rocks. In this aquifer the groundwater occurs either under semi confined condition where the Nubian Sandstone overlained by wadi deposits or under confined condition where it is overlained by the Quseir variegated shales.

ii-The upper aquifer which is composed of sands, gravels and silts has thicknesses ranging from 5 to $20 \mathrm{~m}$ in Wadi EL-Shaghab, and 5 to $10 \mathrm{~m}$ in Wadi Abbad. The groundwater in this aquifer is present in unconfined conditions.

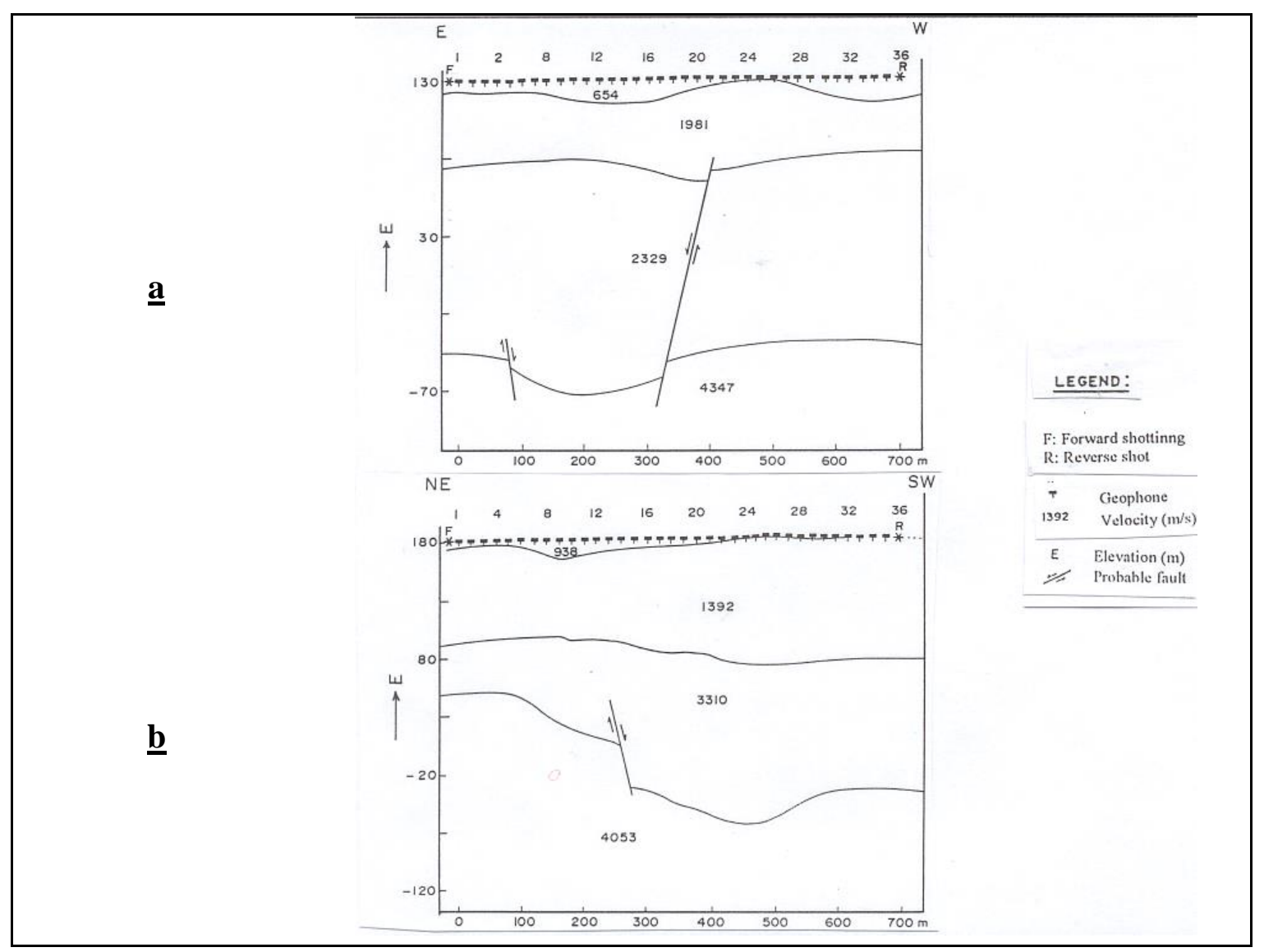

Fig.(4): Geoseismic cross-sections in the Nubian Sandstone plateau (a in Wadi Abbad and $\underline{b}$ in Wadi El Shaghab) 


\section{2-The Mountainous Region Unit:}

The mountainous region represents the main watershed area from which the groundwater flows either to the coastal or to the Nubian aquifers. The groundwater occupies the fissured and weathered zones and occurs in free condition. These water-bearing rocks are covered by thin alluvial deposits increase slightly in thickness towards the down stream parts of the wadis. The depth to the groundwater vary locally ranging between 5 to $21 \mathrm{~m}$. The rainfalls represent the unique recharging source for the groundwater. Limited amounts of the groundwater is kept in the catchment areas while the rest is discharged through the fissures and the fault planes or along the wadi floors either eastwards to the coastal zone or westwards to the Nubian plateau.

In the mountainous areas, three geoelectric zones were distinguished (Fig. 5). The first exhibits very high resitivities (more than 1500 Ohm.m) and has thickness ranges from 1 to $5 \mathrm{~m}$ of dry sands and gravels. The second zone is the saturated fractured zone. Its resistivities ranged between 200 and 600 Ohm.m and its thickness ranges from $5 \mathrm{~m}$ at the upstream portions of the wadies to $25 \mathrm{~m}$ at the downstream portions. The third geoelectric layer composed of fresh basement rocks of high resistivity values (more than 2000 Ohm.m) and unknown thickness.

Three seismic layers were distinguished in the mountainous areas (Fig. 6). The overburden layer ( 2 to $15 \mathrm{~m}$ ) has seismic velocities ranged from 800 to $1500 \mathrm{~m} / \mathrm{s}$. It is overlying fractured rocks (in some parts) having seismic velocities ranged from 1500 to $4000 \mathrm{~m} / \mathrm{s}$ and thickness reaches $30 \mathrm{~m}$ in the main wadies coarses. The later layer is overlying a hard rock in which the seismic velocity exceeds $4500 \mathrm{~m} / \mathrm{s}$.

In the studied areas the groundwater is detected in some fractured Precambrian rocks, in which the thickness are vary locally depending mainly on the weathering and structural features, and on the rocks types. The fractured Precambrian aquifers in the area can be classified according to their origin into four groups:

\section{i-The fractured mtavolcanic aquifer:}

The fractured metavolcanic rocks were detected as water-bearing formation in Wadi Abu-Hammamid and in Wadi El Sukkari. Their thickness in the study area ranges from 5 to $35 \mathrm{~m}$ in which the groundwater is detected at shallow depth, about 3 m (Bir El-Shikh Shazly).

\section{ii-The fractured metasediments aquifer:}

The fractured metasediments include the Migif-Hafafit para-gneisses and migmatites, in which the groundwaters present in free condition. The thickness of this aquifer differs from 20 to $40 \mathrm{~m}$. The depth to water is about 19 m (Bir Hafafit). This aquifer is covered by highly weathered alluvial deposits vary in thickness from 5 to15m.

\section{iii- The fracture plutonic aquifer:}

The fracture granitoids are present as a water bearing formation in Wadi Natash. The thickness of this aquifer is small specially in the upper stream portion where the massive basement rocks outcrop on the surface. Small quantity of water may be expected to be present in this aquifer.

\section{iv-The fracture Hammamat aquifer:}

The fracture Hammamat aquifer is tapped in Wadi Igli. The depth to water in Bir Igli is about $12 \mathrm{~m}$. The groundwater occurs under unconfined condition, where the thickness of wadi deposits is only about $4 \mathrm{~m}$. 

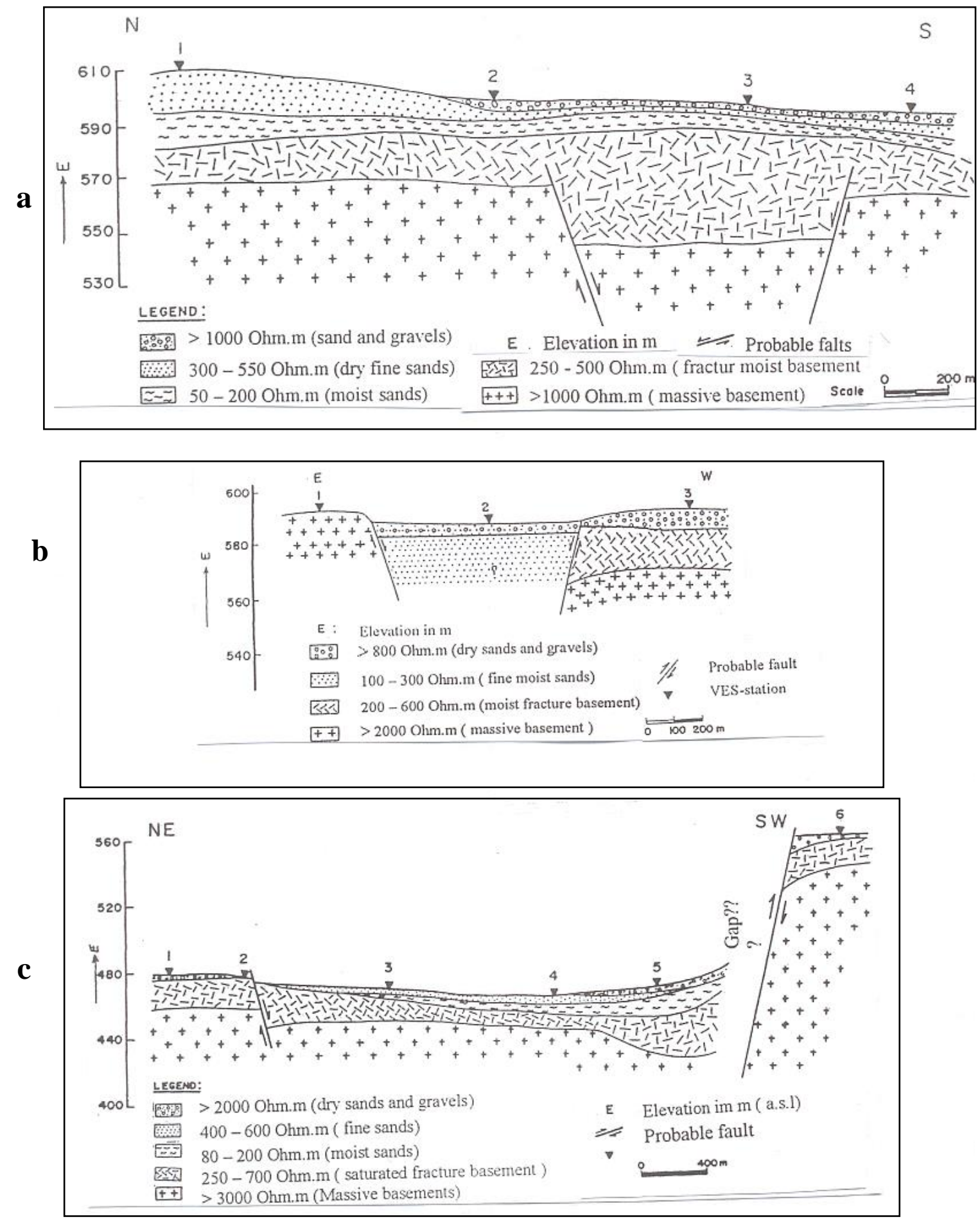

Fig.(5): Geoelectrical cross-sections in the Mountaineous area (a in Wadi Hafafit, $\underline{b}$ in Wadi Natash and $\mathbf{c}$ in Wadi Abu-Hammamat) 
$\mathbf{a}$

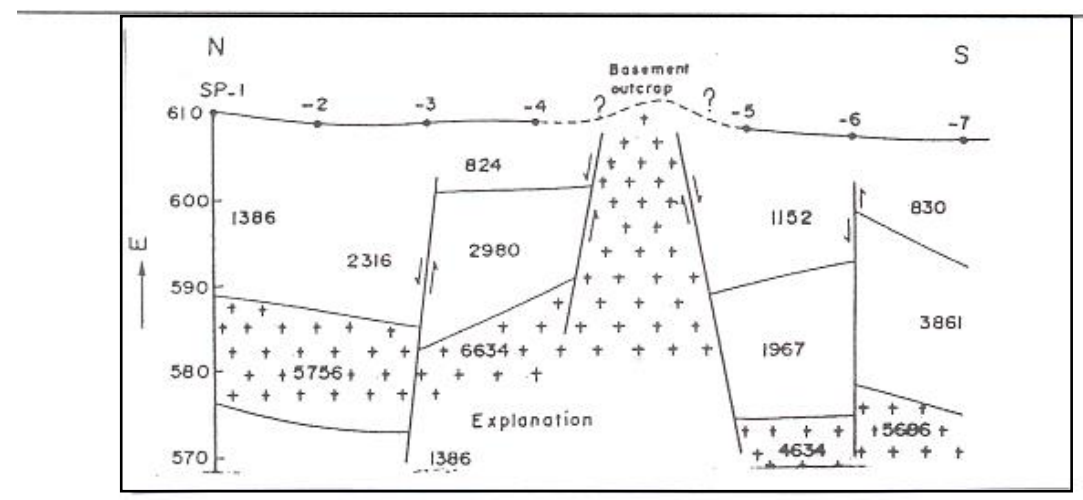

b
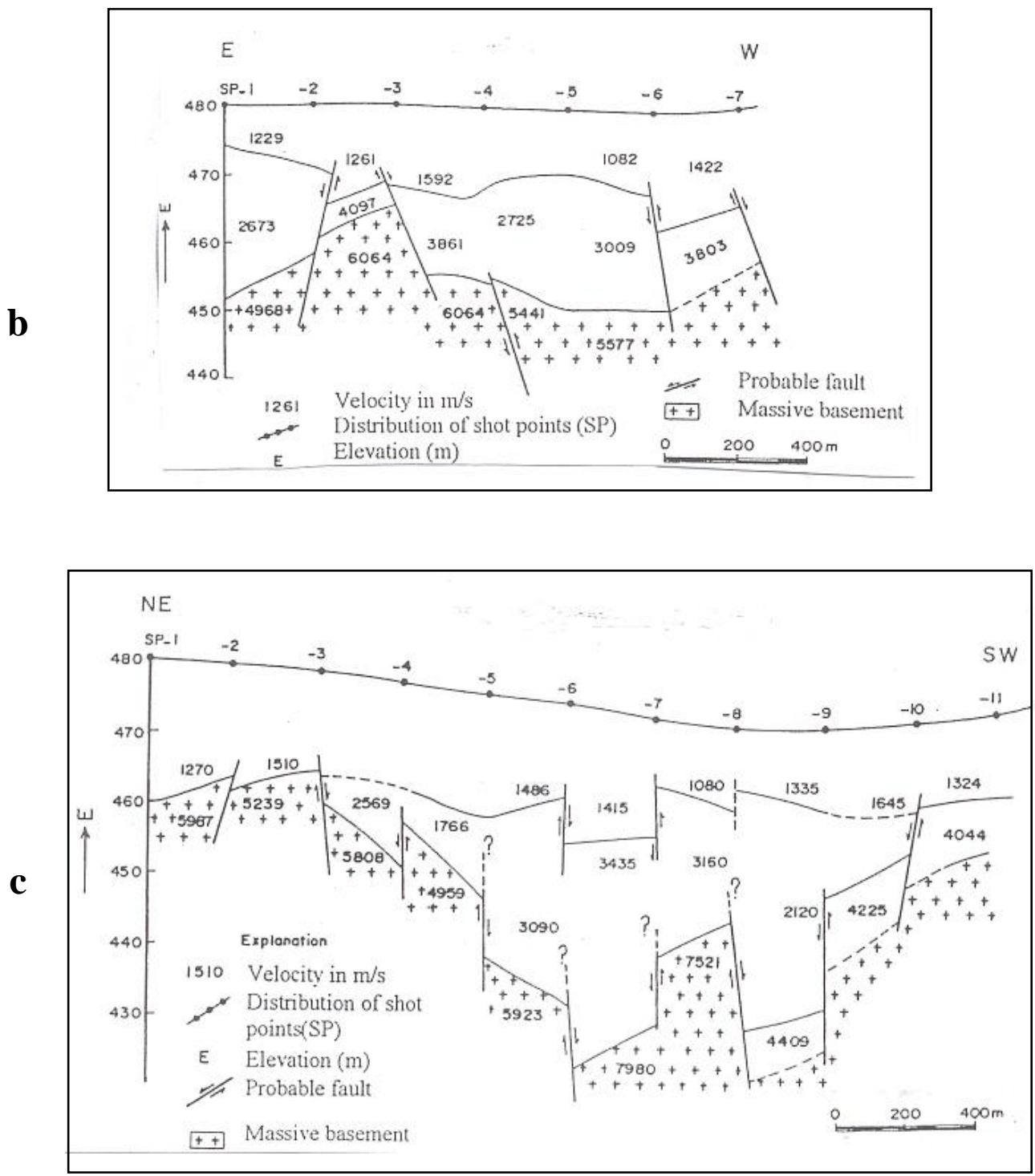

Fig.(6): Geoseismic cross-sections in the mountainous area (a in Wadi Hafafit , $\underline{b}$ in Wadi Natash and $\mathrm{c}$ in Wadi Abu-Hammamat). 


\section{3-The Coastal Unit:}

The coastal zone in the study area includes Wadi Alam and its surrounding areas adjacent to the Red Sea. In Wadi Alam four geoelectric zones were distinguished (Fig.7a). The surface layer which composed of dry alluvial deposits has resistivities ranging from 2000 to more than 4000 Ohm.m. Its thickness ranges from 2 to $7 \mathrm{~m}$, increasing towards the $\mathrm{NE}$ portion of the wadi. The second geoelectric layer has resistivities less than 200 Ohm.m and $60 \mathrm{~m}$ thickness at the middle part of the wadi indicating the presemce of saline water at that part. This layer considered as the main water-bearing layer in Wadi Alam. The third geoelectrical zone has resistivity ranges from 300 to $600 \mathrm{Ohm} . \mathrm{m}$ and about 30m thick. This layer may composed of fractured dolomite limestones. The deeper zone has high resistivity (more than 2000 Ohm.m) and may be composed of massive rocks.

In the coastal plain (W. Alam) four geoseismic layers were revealed (Fig.7b). In the top layer (12 to $36 \mathrm{~m}$ ) the seismic velocity was $900 \mathrm{~m} / \mathrm{s}$. The second layer having variable thickness (8 to $112 \mathrm{~m}$ ) and velocities (2626 to $3295 \mathrm{~m} / \mathrm{s}$ ) due to faulting. The third layer has an average velocity of $4500 \mathrm{~m} / \mathrm{s}$ and 40 to $112 \mathrm{~m}$ thick. The more deeper layer had a velocity about $5160 \mathrm{~m} / \mathrm{s}$ in the NE part increases to 7821 $\mathrm{m} / \mathrm{s}$ in the $\mathrm{SW}$ part near the mountains zone.

Based on the previous studies and on the present geophysical investigation, four waterbearing aquifers in Wadi Alam can be distinguished.

\section{i-The Quaternary alluvial aquifer:}

The Quaternary alluvial deposits in the coastal zone are composed of sands, pebbles, boulders and rock fragments derived mainly during the Pleistocene and the Recent times. Their thickness ranges from 5 to $20 \mathrm{~m}$, where the groundwater lies under unconfined conditions. The groundwater depth-to the south of Marsa Alam-ranged between 2 and $5 \mathrm{~m}$.

\section{ii- Upper Miocene-Pliocene aquifer:}

Upper Miocene-Pliocene aquifer is composed of successive sequences of conglomerates, sandstones, and intercalated shales with gypsum. The thickness of this aquifer ranges between $20 \mathrm{~m} \mathrm{SW}$ Wadi Alam to about $50 \mathrm{~m}$ NE near the sea. The groundwater lies under semi-confined condition where it is overlained by the shale deposits while it lies under unconfined condition at the parts overlained by the Quaternary deposits.

\section{iii-Middle Miocene aquitrad:}

The Middle Miocene sediments are composed of gypsum and marls intercalated with shales and sands. This formation is moderately fractured with thickness ranging from 20 to $60 \mathrm{~m}$ recharges mainly from the water seepage near the mountainous hills.

\section{iv- Oligocene-Middle Miocene aquifer:}

The Oligocene-Middle Miocene aquifer is composed of sandstone intercalated with shale resting unconformably on the basement rocks and overlaid by the fractured gypsum and anhydrates layers. The groundwater occurs under confined to semi-confined conditions. The aquifer is recharged from the groundwater flow from the mountainous rocks. 


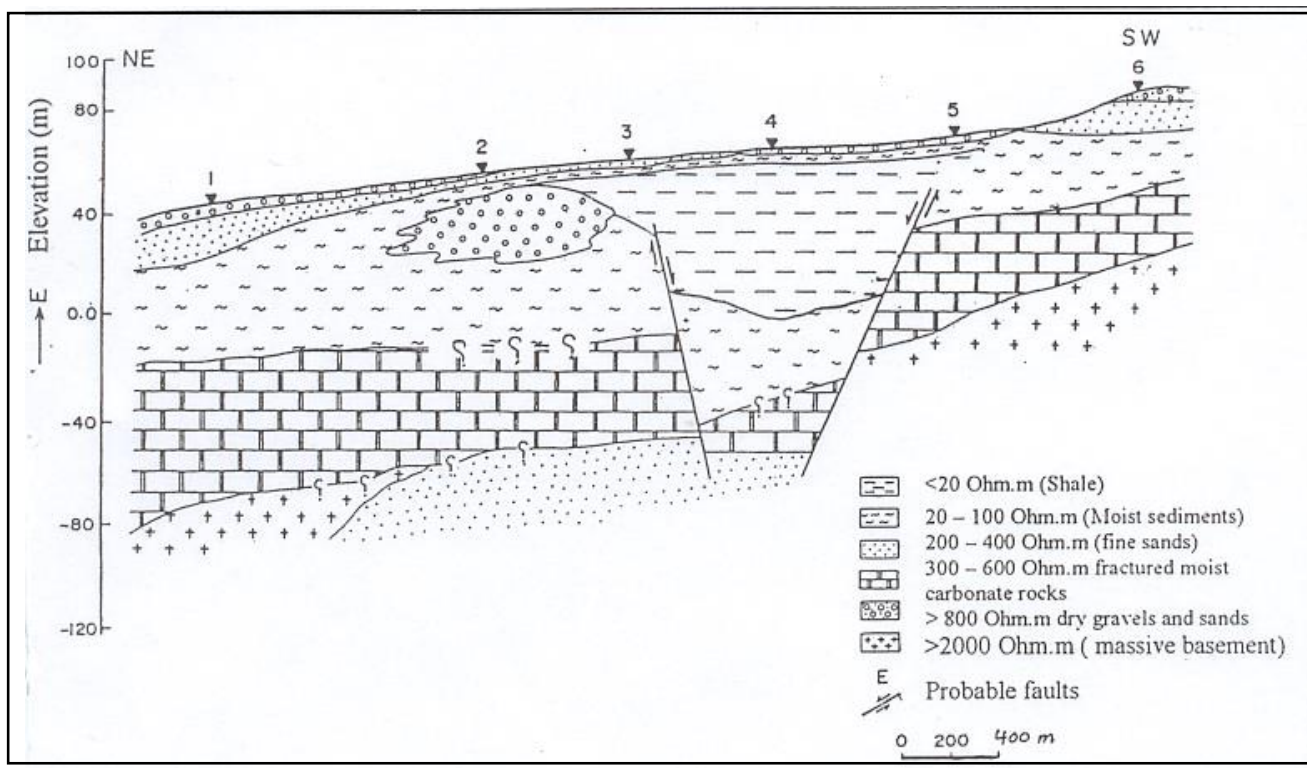

(a)

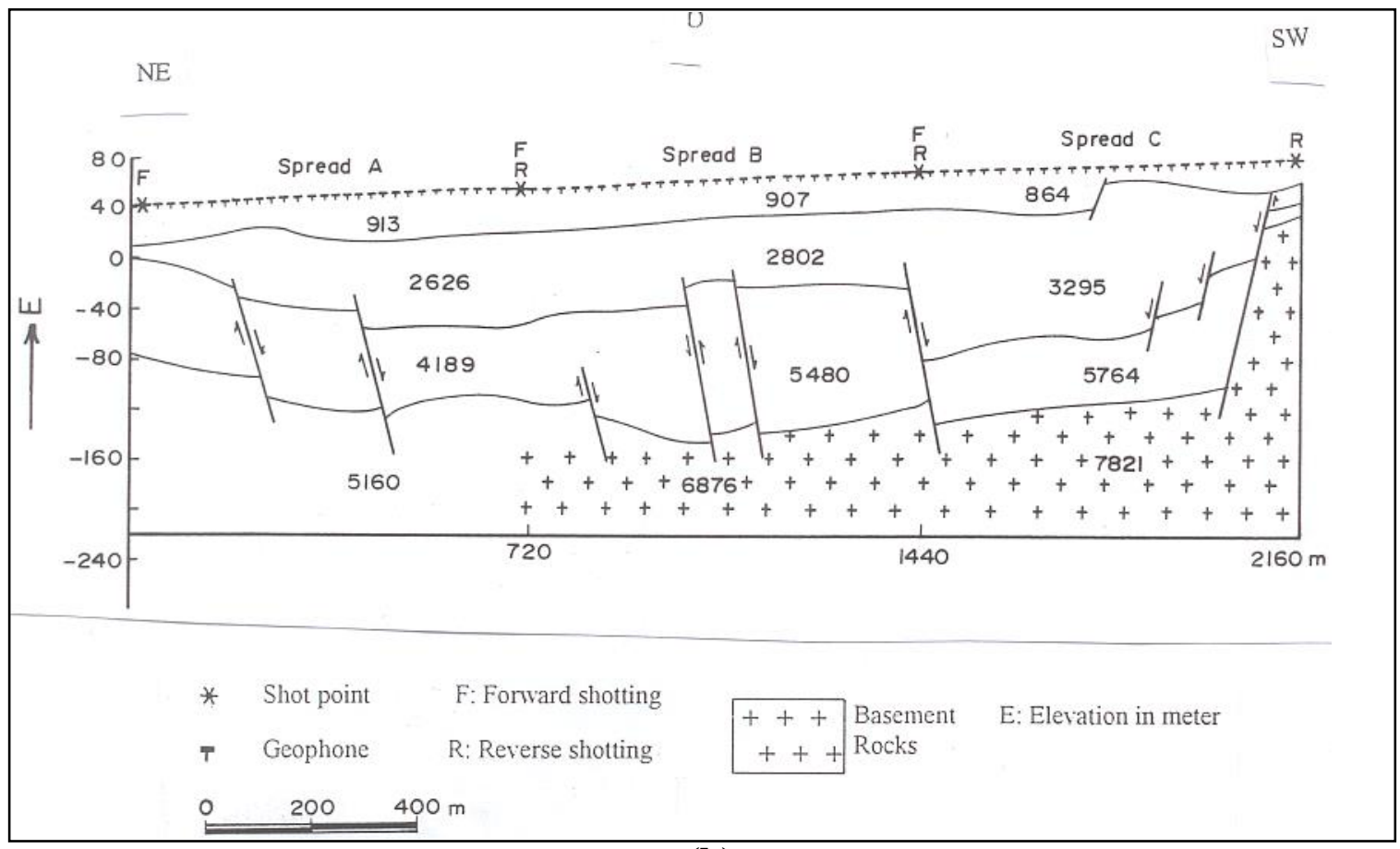

(b)

Fig.(7): Geoelectrical and geoseismic cross-sections in the coastal area "Wadi Alam" a geolectrical cross-section and $\underline{b}$ geoseismic cross-section. 


\section{B-Groundwater Chemistry:}

The hydrogeochemical investigation in the present study is restricted to the major ions concentrations, distributions, their relative abundance, and the pattern of the variability in groundwater chemistry. On the bases of the groundwater chemistry an evaluation of groundwater for domestic and irrigation uses is established.

The $\mathbf{p H}$ values of the representative samples range between 7.5 well No 2 Table (2) shows the result of the chemical of the analysis 8.5 Marsa Alam. The groundwater ranges from slightly saline (TDS 1000 to $3000 \mathrm{ppm}$ ) to moderately saline (TDS 3000 to $5300 \mathrm{ppm}$ ). Groundwater of salinity less than $1000 \mathrm{ppm}$ is recorded in Barramia (well No.3) which penetrates coarse texture rhyolite contacting the Nubian Sandstones. Groundwater with salinities between 2000 to $3200 \mathrm{ppm}$ were found in Nubian sandstone aquifer in Abbad (well No.2) and in the upstream portions of the wadies in the mountainous areas (Sukkari, well No.6 and Igli, well No. 7). The considerable moderate salinity of these waters is mainly due to the limit effect of leaching processes. Groundwater with salinities more than $3500 \mathrm{ppm}$ is recorded in the coastal areas and in the downstream portions in the mountainous areas (Hafafit well No. 5 and El-Shazly well No. 6). The increase in salinity values in these parts is attributed mainly to long path of water flow and to the effects of the marine sediments or to the saline water intrusion in the coastal areas.

Table (2): Chemical analysis results of the collected groundwater samples (October/2000)

\begin{tabular}{|c|c|c|c|c|c|c|c|c|c|c|c|c|c|c|c|}
\hline $\begin{array}{c}\text { Sample } \\
\text { No. }\end{array}$ & Area & $\mathrm{pH}$ & $\begin{array}{c}\mathrm{EC} \\
\mu \mathrm{s} / \mathrm{cm}\end{array}$ & $\begin{array}{l}\text { TDS } \\
\text { ppm }\end{array}$ & Unit & $\mathrm{Ca}^{++}$ & $\mathrm{Mg}^{++}$ & $\mathrm{Na}^{+}$ & $\mathbf{K}^{+}$ & $\mathrm{HCO}_{3}{ }^{\circ}$ & $\mathrm{SO}_{4^{-}}{ }^{2}$ & $\mathrm{Cl}^{-}$ & $\begin{array}{c}\text { TH } \\
\text { ppm }\end{array}$ & $\begin{array}{c}\text { SAR } \\
\text { Meq/I }\end{array}$ & $\begin{array}{l}\mathrm{Na} \% \\
\text { Meq/I }\end{array}$ \\
\hline $1 c$ & $\begin{array}{c}\text { Nile } \\
\text { Water }\end{array}$ & 9.11 & 610 & 391 & $\begin{array}{c}\text { Ppm } \\
\text { Meq/I } \\
\%\end{array}$ & $\begin{array}{c}20 \\
1 \\
18\end{array}$ & $\begin{array}{c}48.6 \\
4 \\
71\end{array}$ & $\begin{array}{c}11.96 \\
0.52 \\
9\end{array}$ & $\begin{array}{c}3.13 \\
0.08 \\
1\end{array}$ & $\begin{array}{c}155.7 \\
2.55 \\
41\end{array}$ & $\begin{array}{l}115 \\
2.4 \\
42\end{array}$ & $\begin{array}{c}35.4 \\
1 \\
17\end{array}$ & 250 & 0.33 & 10.7 \\
\hline $2 \mathrm{c}$ & Abbad & 7.48 & 3580 & 2295 & $\begin{array}{c}\text { Ppm } \\
\text { Meq/I } \\
\%\end{array}$ & $\begin{array}{c}176.4 \\
8.8 \\
25\end{array}$ & $\begin{array}{c}85 \\
7 \\
20\end{array}$ & $\begin{array}{c}436.5 \\
18.98 \\
54\end{array}$ & $\begin{array}{c}18 \\
0.46 \\
1\end{array}$ & $\begin{array}{c}334 \\
5.47 \\
15\end{array}$ & $\begin{array}{c}331 \\
6.9 \\
19\end{array}$ & $\begin{array}{c}815 \\
23 \\
65\end{array}$ & 790 & 6.9 & 55.2 \\
\hline $3 c$ & Barrmia & 8.25 & 1530 & 981 & $\begin{array}{c}\text { Ppm } \\
\text { Meq/I } \\
\%\end{array}$ & $\begin{array}{l}52 \\
2.6 \\
18\end{array}$ & $\begin{array}{c}26.7 \\
2.2 \\
15\end{array}$ & $\begin{array}{c}222 \\
9.65 \\
65\end{array}$ & $\begin{array}{c}12 \\
0.31 \\
2\end{array}$ & $\begin{array}{c}33.6 \\
5.47 \\
37\end{array}$ & $\begin{array}{l}235 \\
4.9 \\
33\end{array}$ & $\begin{array}{c}159.5 \\
4.5 \\
30\end{array}$ & 240 & 6 & 67.5 \\
\hline $4 c$ & Hafafit & 7.67 & 6750 & 4327 & $\begin{array}{c}\text { Ppm } \\
\text { Meq/I } \\
\%\end{array}$ & $\begin{array}{c}108.3 \\
5.4 \\
8\end{array}$ & $\begin{array}{c}87.5 \\
7.2 \\
11\end{array}$ & $\begin{array}{c}1225 \\
53.26 \\
80\end{array}$ & $\begin{array}{c}40 \\
0.87 \\
1\end{array}$ & $\begin{array}{c}742 \\
12.16 \\
18\end{array}$ & $\begin{array}{c}1320 \\
27.5 \\
41\end{array}$ & $\begin{array}{c}939.4 \\
26.5 \\
40\end{array}$ & 630 & 21.2 & 81.1 \\
\hline $5 c$ & Shazly & 8.16 & 7910 & 5070 & $\begin{array}{c}\text { Ppm } \\
\text { Meq/I } \\
\%\end{array}$ & $\begin{array}{c}204.5 \\
10.2 \\
13\end{array}$ & $\begin{array}{c}213 \\
17.6 \\
23\end{array}$ & $\begin{array}{c}1150 \\
50 \\
63\end{array}$ & $\begin{array}{c}7 \\
0.18 \\
2\end{array}$ & $\begin{array}{c}148 \\
3.95 \\
3\end{array}$ & $\begin{array}{c}2141 \\
44.5 \\
57\end{array}$ & $\begin{array}{c}1046 \\
29.5 \\
38\end{array}$ & 1441 & 13 & 64.4 \\
\hline $6 c$ & Sukkary & 7.53 & 5130 & 3288 & $\begin{array}{c}\text { Ppm } \\
\text { Meq/I } \\
\%\end{array}$ & $\begin{array}{c}160 \\
8 \\
16\end{array}$ & $\begin{array}{c}116.6 \\
6.9 \\
19\end{array}$ & $\begin{array}{c}756 \\
32.9 \\
65\end{array}$ & $\begin{array}{c}5 \\
0.13 \\
2\end{array}$ & $\begin{array}{c}185.4 \\
3.04 \\
6.3\end{array}$ & $\begin{array}{c}1133 \\
23.6 \\
47\end{array}$ & $\begin{array}{c}762 \\
21.5 \\
43\end{array}$ & 879 & 11 & 68.9 \\
\hline $7 c$ & Ilgi & 7.97 & 4090 & 2621 & $\begin{array}{c}\text { Ppm } \\
\text { Meq/I } \\
\%\end{array}$ & $\begin{array}{c}176.4 \\
8.8 \\
22\end{array}$ & $\begin{array}{c}85 \\
7 \\
17\end{array}$ & $\begin{array}{c}557 \\
24.22 \\
60\end{array}$ & $\begin{array}{c}14 \\
0.36 \\
1\end{array}$ & $\begin{array}{c}119 \\
1.95 \\
5\end{array}$ & $\begin{array}{c}288 \\
6 \\
15\end{array}$ & $\begin{array}{c}1152 \\
32.5 \\
80\end{array}$ & 790 & 9 & 60.9 \\
\hline $8 c$ & Anbaout & 8.18 & 8240 & 5282 & $\begin{array}{c}\text { ppm } \\
\text { meq/I } \\
\%\end{array}$ & $\begin{array}{c}557.4 \\
27.8 \\
34\end{array}$ & $\begin{array}{c}172.5 \\
14.2 \\
17\end{array}$ & $\begin{array}{c}900 \\
39.13 \\
48\end{array}$ & $\begin{array}{c}38 \\
0.97 \\
1\end{array}$ & $\begin{array}{c}55.5 \\
0.91 \\
1\end{array}$ & \begin{tabular}{c|}
1690 \\
35.2 \\
43
\end{tabular} & $\begin{array}{c}1631 \\
46 \\
56\end{array}$ & 2100 & 8.5 & 48.8 \\
\hline $9 c$ & Ghadier & 8.23 & 5870 & 3763 & $\begin{array}{c}\text { ppm } \\
\text { meq/I } \\
\%\end{array}$ & $\begin{array}{c}337 \\
16.8 \\
29\end{array}$ & $\begin{array}{c}146 \\
12 \\
20\end{array}$ & $\begin{array}{c}657 \\
28.56 \\
49\end{array}$ & $\begin{array}{c}27 \\
0.69 \\
1\end{array}$ & $\begin{array}{c}74.4 \\
1.22 \\
2\end{array}$ & $\begin{array}{c}518 \\
10.8 \\
19\end{array}$ & $\begin{array}{c}1631 \\
46 \\
79\end{array}$ & 1441 & 7.5 & 50.4 \\
\hline
\end{tabular}


The results of the chemical analysis show that sodium-chloride is the dominant salts in the water samples followed by sodium-sulphate and magnesium-sulphate in mountainous zone and by calcium-sulphate in the coastal zone (Table 3).

Table (3): Ions dominance and hypothetical salts of the collected groundwater samples.

\begin{tabular}{|c|c|c|c|c|c|}
\hline $\begin{array}{l}\text { Hydrogeological } \\
\text { zone }\end{array}$ & Sample & Aquifer & Ions Dominance & Hypothetical salts & Remark \\
\hline Nile & $\begin{array}{c}1 \\
\text { (Nile) }\end{array}$ & & $\begin{aligned} \mathrm{Mg} & >\mathrm{Ca}>\mathrm{Na}>\text { and } \\
\mathrm{HCO}_{3} & >\mathrm{SO}_{4}>\mathrm{Cl}\end{aligned}$ & $\begin{array}{c}\mathrm{Mg}\left(\mathrm{HCO}_{3}\right)_{2}, \mathrm{Ca}\left(\mathrm{HCO}_{3}\right)_{2}, \mathrm{MgSo}_{4}, \mathrm{a} \\
\text { nd } \mathrm{NaCl}\end{array}$ & $\begin{array}{l}\text { Fresh } \\
\text { water }\end{array}$ \\
\hline Nubian sandstone & $\begin{array}{c}2 \\
\text { (Abbad) }\end{array}$ & $\begin{array}{l}\text { Nubian } \\
\text { sandstone }\end{array}$ & $\begin{array}{c}\mathrm{Na}>\mathrm{Mg}>\mathrm{Ca}>\text { and } \\
\mathrm{Cl}>\mathrm{HCO}_{3}>\mathrm{SO}_{4}\end{array}$ & $\begin{array}{c}\mathrm{NaCl}, \mathrm{Ca}\left(\mathrm{HCO}_{3}\right)_{2} \\
\mathrm{MgSo}_{4}, \mathrm{CASo}{ }_{4} \text { and } \mathrm{MgCl}_{2}\end{array}$ & \\
\hline \multirow{5}{*}{ Mountainous zone } & $\begin{array}{c}3 \\
\text { Barramia }\end{array}$ & Igneous & $\begin{array}{l}\mathrm{Na}>\mathrm{Ca}>\mathrm{Mg} \text { and } \\
\mathrm{HCO}_{3}>\mathrm{SO}_{4}>\mathrm{Cl}\end{array}$ & $\begin{array}{c}\mathrm{NaSo}_{4}, \mathrm{NaCl}, \mathrm{Ca}\left(\mathrm{HCO}_{3}\right)_{2} \text {, and } \mathrm{Mg} \\
\left(\mathrm{HCO}_{3}\right)_{2}\end{array}$ & fresh \\
\hline & $\begin{array}{c}4 \\
\text { (Hafafit) }\end{array}$ & Metasediment & $\begin{array}{c}\mathrm{Na}>\mathrm{Mg}>\mathrm{Ca}>\text { and } \\
\mathrm{SO}_{4}>\mathrm{Cl}>\mathrm{HCO}_{3}\end{array}$ & $\begin{array}{c}\mathrm{MgSO}_{4}, \mathrm{NaCl}, \mathrm{Mg}\left(\mathrm{HCO}_{3}\right)_{2}, \mathrm{Ca}(\mathrm{HC} \\
\left.\mathrm{O}_{3}\right)_{2}, \text { and } \mathrm{Na}\left(\mathrm{HCO}_{3}\right)_{2}\end{array}$ & $\begin{array}{l}\text { Meteoric } \\
\text { water }\end{array}$ \\
\hline & $\begin{array}{c}5 \\
\text { (Shazly) }\end{array}$ & Metavolcanic & $\begin{array}{l}\mathrm{Na}>\mathrm{Mg}>\mathrm{Ca}>\text { and } \\
\mathrm{SO}_{4}>\mathrm{Cl}>\mathrm{HCO3}\end{array}$ & $\begin{array}{c}\mathrm{NaCl}, \mathrm{NaSO}_{4} \mathrm{Mg} \mathrm{SO}_{4}, \mathrm{Ca} \\
\mathrm{SO}_{4} \text { and } \mathrm{Ca}\left(\mathrm{HCO}_{3}\right)_{2}\end{array}$ & \multirow{2}{*}{$\begin{array}{c}\text { Abundant } \\
\text { Sulfate }\end{array}$} \\
\hline & $\begin{array}{c}6 \\
\text { (Sukkari) }\end{array}$ & Metavolcanic & $\begin{array}{l}\mathrm{Na}>\mathrm{Mg}>\mathrm{Ca}>\text { and } \\
\mathrm{SO} 4>\mathrm{Cl}>\mathrm{HCO}_{3}\end{array}$ & $\begin{array}{c}\mathrm{NaCl}, \mathrm{Mg} \mathrm{SO} \mathrm{Sa} \mathrm{SO}_{4}, \mathrm{Ca}\left(\mathrm{HCO}_{3}\right)_{2} \\
\text { and } \mathrm{Ca} \mathrm{SO}_{4}\end{array}$ & \\
\hline & $\begin{array}{c}7 \\
\text { (Igli) }\end{array}$ & Hammamat & $\begin{array}{c}\mathrm{Na}>\mathrm{Mg}>\mathrm{Ca}>\text { and } \\
\mathrm{Cl}>\mathrm{SO}_{4}>\mathrm{HCO}_{3}\end{array}$ & $\begin{array}{c}\mathrm{NaCl}, \mathrm{MgCl}_{2}, \mathrm{Ca} \mathrm{SO}_{4}, \mathrm{Ca}\left(\mathrm{HCO}_{3}\right)_{2} \\
\text { and } \mathrm{CaCl}\end{array}$ & \\
\hline Coastal & $\begin{array}{c}8 \\
\text { (Anbaout) }\end{array}$ & Alluvium & $\begin{array}{c}\mathrm{Na}>\mathrm{Mg}>\mathrm{Ca}>\text { and } \\
\mathrm{Cl}>\mathrm{SO}_{4}>\mathrm{HCO}_{3}\end{array}$ & $\begin{array}{c}\mathrm{NaCl}, \mathrm{Ca} \mathrm{SO} \\
\mathrm{Ca}_{4}, \mathrm{Mg} \mathrm{SO}_{4}, \mathrm{MgCl}_{2} \text { and } \\
\end{array}$ & Sea water \\
\hline Zone & $\begin{array}{c}9 \\
\text { (Ghadeir) }\end{array}$ & Alluvium & $\begin{aligned} \mathrm{Na} & >\mathrm{Mg}>\mathrm{Ca}>\text { and } \\
\mathrm{Cl} & >\mathrm{SO}_{4}>\mathrm{HCO}_{3}\end{aligned}$ & $\begin{array}{c}\mathrm{NaCl}, \mathrm{MgCl}_{2}, \mathrm{Ca} \mathrm{SO}_{4}, \mathrm{CaCl}_{2} \text { and } \\
\mathrm{Ca}\left(\mathrm{HCO}_{3}\right)_{2}\end{array}$ & $\begin{array}{c}\text { Marine } \\
\text { facies }\end{array}$ \\
\hline
\end{tabular}

In Piper Diagram (Fig. 8) most of the groundwater samples are scattered in the right side of the upper triangle of the diamondshaped field and extended along the vertex $\mathrm{Ca}$ and Mg. In this part most saline waters, and sea water are situated. So these samples are characterized by advanced mineralization stage and reveal a direct impact of marine deposits.

Table(4):Water quality classification based on EC or (TDS) and Na\% according to Wilcox (1948)

\begin{tabular}{|c|c|c|c|c||}
\hline Class & Na \% & Sample No. & EC $\mu$ s/cm & Sample No. \\
\hline Excellent & $<20$ & 1 & $<250$ & \\
Good & $20-40$ & & $250-750$ & 1 \\
Permissible & $40-60$ & 2,7 & $750-2000$ & 3 \\
Doubtful & $60-80$ & $3,5,6,8,9$ & $2000-3000$ & 2 \\
Unsuitable & $>80$ & 4 & $>3000$ & $2,4,5,6,7,8,9$ \\
\hline
\end{tabular}




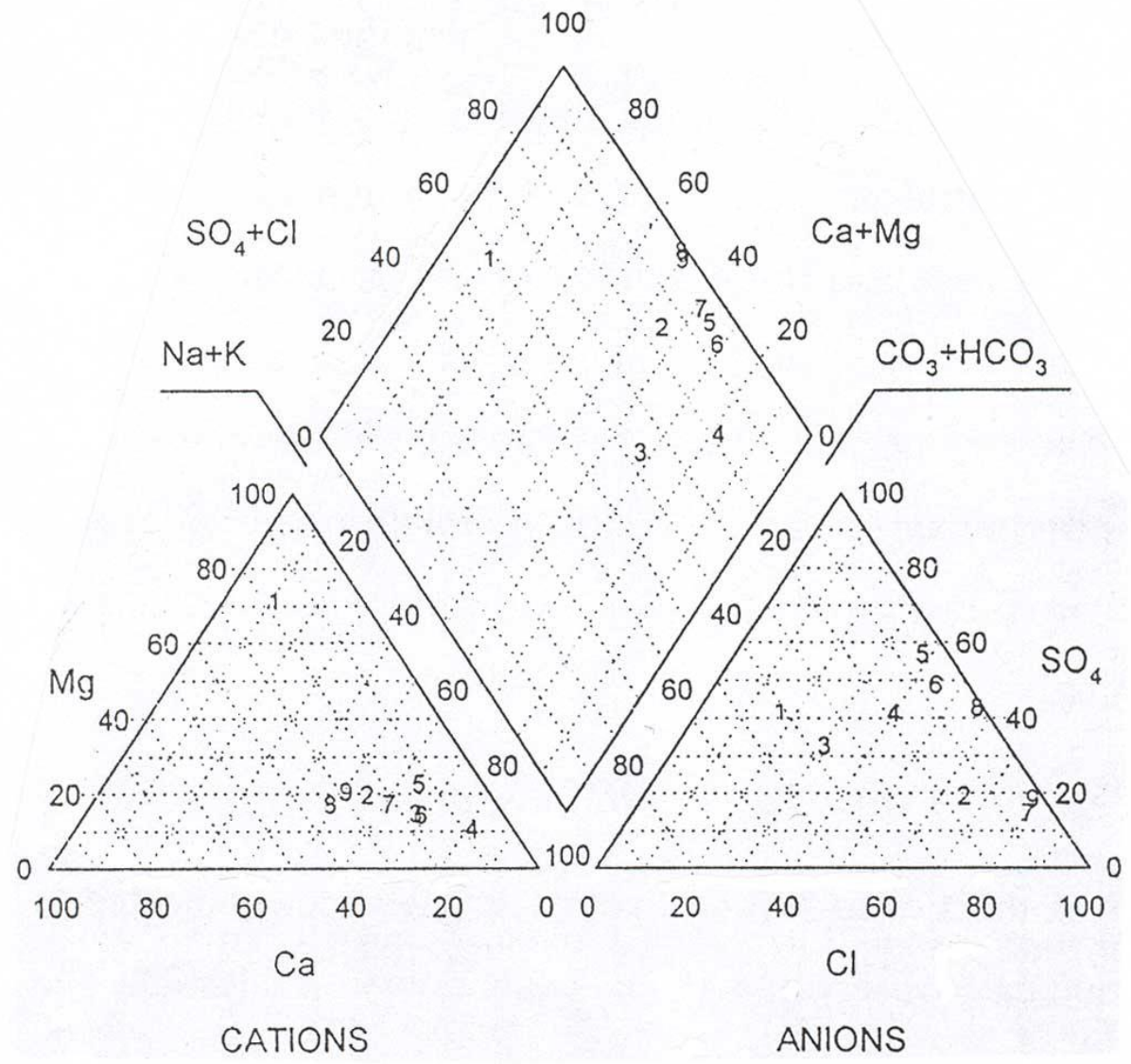

Fig. (8): Distribution of the water samples on Piper Diagram.

\section{C- Groundwater Quality :}

Different chemical quality standards have been established for evaluating the water suitability for drinking, domestic and irrigation uses. In the present study the groundwater suitability for different uses is based on the concentration of its major ions constituents:

\section{1-Groundwater Quality For Drinking and Domestic Uses :}

The evaluation of ground quality for drinking and domestic uses, is attempted depending on some international standards, suggested by the World Health Organization (WHO, 1984) and the U.S. Environmental Protection Agency.
Most of the groundwater samples have total dissolved solids (TDS) and total hardness (TH) in addition to of calcium, magnesium and bicarbonate ions, concentrations specially in the mountainous areas exceed the safe limits for drinking use. So most of groundwater in the area are not suitable for drinking except that in Barramia locality.

\section{2-Groundwater Quality for Livestock and Poultry Uses:}

The evaluation of the groundwater for livestock and poultry uses is based on Hem, (1970) and the National Academy of Science (1972) limitations. 
According to Hem's classification, all groundwater in the area are suitable for all livestock classes and only three ground water points, (wells No.2,3 and 7) are acceptable for poultry consumption.

According to the classification of National Academy of Science,1972 the groundwater in the study area can be classified into three main categories; a- Excellent water for all livestock and poultry classes (TDS $<1000 \mathrm{mg} / \mathrm{l}$ ) in well No3. b-Very satisfactory (TDS1000$3000 \mathrm{mg} / \mathrm{l})$ for the groundwater in the wells No.2 and 7. c- Satisfactory water for livestock and poor for poultry (TDS 3000-5000 $\mathrm{mg} / \mathrm{l}$ ) in wells No. 4,5 and 9. On the other hand, the groundwater in well No. 8, can be used with reasonable safety for livestock and not acceptable for poultry.

\section{3-Groundwater Quality for Irrigation Purposes:}

Several chemical constituents affect water suitability for irrigation from which the total concentration of the soluble salts and the relative proportion of sodium to calcium and magnesium. Moreover suitability of water for irrigation is depended on the effect of some mineral constituents in the water on both the soil and the plant (Wilcox, 1948 \& 1955).

Regarding to the TDS content the water is considered satisfactory when it contains lesser than $1000 \mathrm{mg} / \mathrm{l}$, fair if it contains between 1000 to $2000 \mathrm{mg} / \mathrm{l}$, and inferior when it salinity exceeds 2000mg/l. Accordingly, only the groundwater in Barramia (well 3) is considered suitable for irrigation uses.

The sodium percentages in the studied samples ranged between $11 \%$ (Nile water) to $81 \%$ (Hafafit well No.4). According to Wilcox Classification, the ground-waters in the study area is ranging between permissible to doubtful for irrigation uses.

The groundwater quality in the area is evaluated also taken both the TDS and SAR values in consideration based of the irrigation water which based in turn on EC or TDS and SAR. The analyzed samples were plotted on Wilcox diagram (Fig. 9) where the groundwater in shallow Nubian sandstone aquifer in Abbad (well No.2) lies in (C4-S2) class, and the groundwater in Igli (No.7) lies in (C4-S3) class. These groundwaters are unsuitable for irrigation in most soils and require special soil management, good drainage, high leaching and organic matter additions. The groundwater in Barramia (well No.3) lies in (C3-S2) class, which presents an appreciable sodium hazard in the fine-textured soils especially under lowleaching conditions. On the other hand, the groundwater samples in the coastal zone, and those of the downstream portions of the mountainous areas having high salinity and their EC are more than 5000 (micromohos/cm). So these samples lie out of the diagram. 


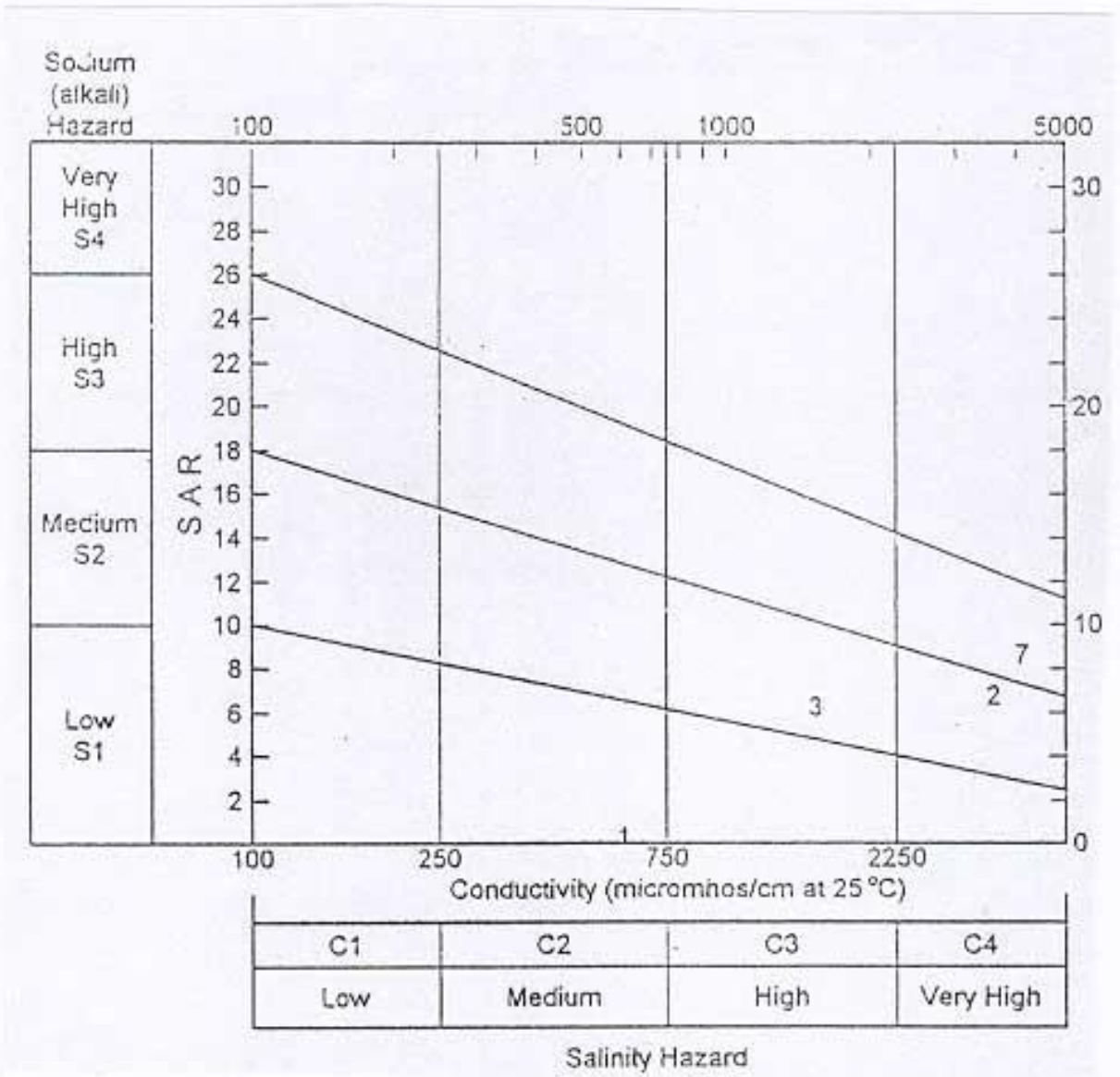

Fig. (9): Water classification according to TDS and SAR values.

\section{CONCLUSIONS:}

Idfu-Marsa Alam district is considered one of the promising area in which the groundwater can be used for development. The use of the electrical resistivity and the seismic refraction methods for exploration and detection the water-bearing formations in the area produced reasonable results. The study showed that the Nubian Sandstone unit is the most important hydrogeological unit in the area regarding to its geometry. The main groundwater type in the area is Sodium - Chloride. The groundwater regime and quality in the area is mainly controlled by the water-bearings composition and site - up or down of the wadies coarse. The groundwater in the area cannot be used safely for drinking and laundry purposes, except in Barramia and Igla wells. However, all groundwater are suitable for all livestock classes and only in some parts it can be used for poultry consumption. For irrigation uses only the groundwater in Barramia can be accepted. 


\section{REFERENCES:}

Abdel Mogheeth, S.M., Misak, R.F. Atwa, S.M., Abdel Baki, A.A. and Sallouma, M.K., (1988): On the chemical properties of groundwater in selected fractured granitoids in Sinai and Eastern Desert. Egypt, Desert Inst. Bull., A.R.E., 38, (1-2), 19-40.

Akaad, M.K., and Noweir, A.M., (1969): Lithostratigraphy of the HammamatUmseleimat district, Eastern Desert, Egypt. Nature, Vol. 223, 284-285.

Akaad,M.K. and Noweir, A.M., (1980): Geology and Lithostratigraphy of the Hammamat at Um Seleimat district, eastern desert, Egypt Nature 223, 284-285.

Attia, A.H., (1999) : Geoenvironmental studies in Marsa Alam area between lat $\left(24^{0} 00^{\circ}\right.$ $\left.25^{\circ} 00^{\prime}\right)$ and long $\left(34^{0} 30^{`}-35^{\circ} 00^{\prime}\right)$. (M.Sc. Thesis, Ein Shams Univ. Cairo: 180.

David K.Todd,(1959):Groundwater Hydrology., (John Wiley \& Sons, Inc. Toppan Company, Ltd., Tokyo, Japan pp. 335.

El-Ramly, M.F., and Akaad, M.K., (1960): The basement complex in the central Eastern Desert of Egypt, between Lat. $24^{0} 40^{\circ}$ and $25^{\circ} 40^{\circ}$. Geol. Surv. Cairo, papers, No.8, 35.

El-Shazly, E.M., (1964) : On the classification of the Precambrian and other rocks of the magmatic affiliation in Egypt. 22 ${ }^{\text {nd }}$ Int. Geol. Con. India, Sec. Vol. 10, 394.

Hem, J.D., (1970) : Study and interpretation of the chemical characteristics of the Natural Water, U.S. Geol. Sur., Water supply paper, 197, 363.

Khaled, M.A., Geological and geophysical investigations for groundwater potentialities in El-Quseir-Abu Ghusun area, south of the Eastern Desert, Egypt. (M.Sc. Thesis, Cairo Univ. 1995)

Misak R.F. and Abdel Baki, A.A. (1990): Classification of Phanerozoic aquifers in the Eastern Desert with emphasis on the newly explred one, Bull. Fac. Sci. Assiut Univ., 20, 19-38.

Mohran, Sedimentology and General Stratigraphy of the Pliocene Sediments of The Red Sea Coastal Area, Egypt. (PH.D Thesis, Assiut Univ. 345, (1990).

National Academy of Science and National Academy of Engineering, Water quality protection agency: Washington, D.C, (1972), 1-594.

Orellana, E., and Mooney, H. M., (1966): Master tables and curves for vertical electrical sounding over layered structures. Madrid, Interciecia, 150 pp. and 66 Tables.

Piper, A.M., (1953): A graphic procedure in the geochemical interpretation of water analyses. U.S. Geol. Survey Groundwater Note 12.

Richard, L.A., (1954): Diagnosis and improvement of Saline and Alkali Soils. Agric. Handbook 60, (U.S. Dept. Agric., Washington, D.C., 160 pp .

Timonthy, A.L., Lawrence, L., and Malinconico, J., (1987): "SEISVIEW', computer program of intercept-time interpretation method for refraction seismic data.

Van Der Velpen, B.P.A., (1988): "RESIST", Version 1.0, a package for the processing of the resistivity sounding data. (M.Sc. Research project, ITC, Delft, the Netherlands.

Ward, W.C. and McDonald, K.C., (1979): Nubia Formation of central Eastern 
Desert, Egypt, major subdivisions and depositional setting. The AAPG. Bull.V. 63, No.6, 983.

Wilcox, L.V., (1948): The quality of water for irrigation use, U.S. Dept., Agric. Tech. Bull. 962, Washington, D.C. 40 pp.

Wilcox, L.V., (1955): Classification and use of irrigation water, U.S. Dept. Agric. Circ. 969, Washington, D.C., 19 pp.

World Health Organization, Guideline for drinking water quality. WHO, Geneva, Switzerland, Vol.1; Recommendations, (1984).
Yousef, E.A.A., (1979) : Sedimentological studies of some Pliocene-Pleistocene sediments at Mersa Alam area, Red Sea Coast, Egypt, Part 1, Pliocene algal carbonates, Egypt, J, Geol. Surv. Cairo, Egypt. Vol. 28, No.2, 321-330.

Zohdy, A.A.R. and Bischrof, R. J., (1989) : Programs for the automatic processing and interpretation of Schlumberger sounding curves in Quick Basic 40: US., Geol., Survey, Denver, Col. USA. 
استخدام الطرق الجيوفيزيائية والهيدروجيولوجية فى استكثاف وتقييم المياه الجوفية

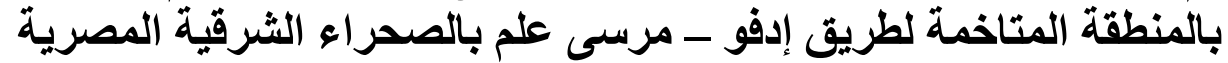

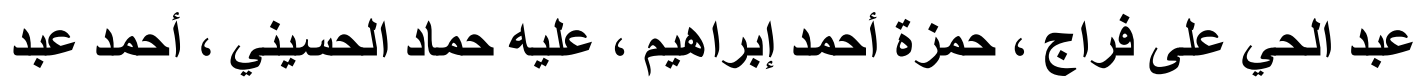
القادر

$$
\text { قسم الجيولوجيا - كلية العلوم - جامعة أسيوط }
$$

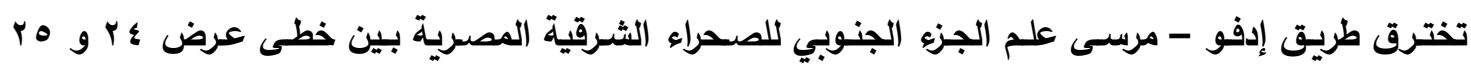

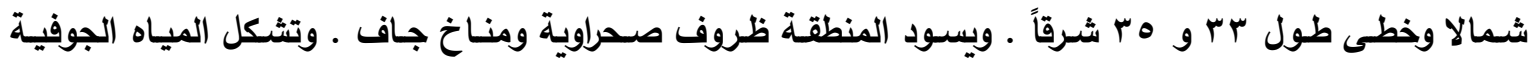
بالمنطقة أهمية كبيرة حيث تمثل مصدر المياه الوحيد للشرب وللمراعى. تهاف الدارسة الحالية أساساً إلى استكثاف وتقييم المياه الجوفية بالمنطقة، ولقد تم اختيار بعض المناطق

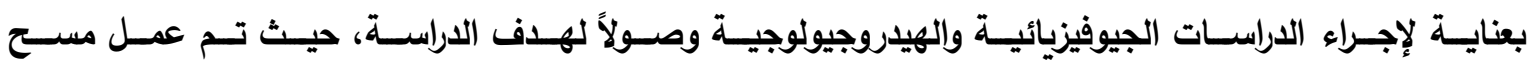

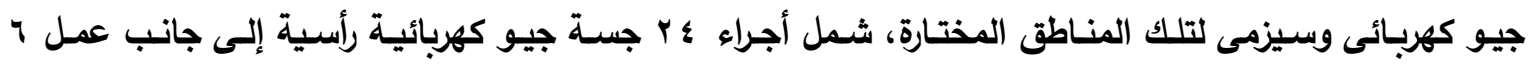

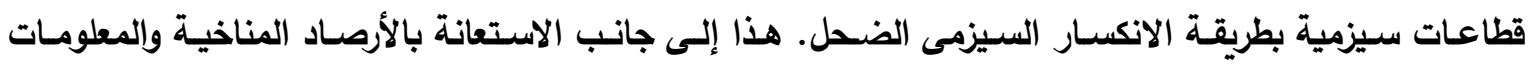

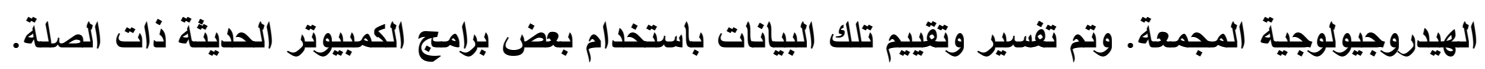
ولتقد أمكن تمييز وتحديد ثلاث أنواع رئيسية من خزانات المياه الجوفية بالمنطقة. هذا وقد خلصت الدراسة إلى

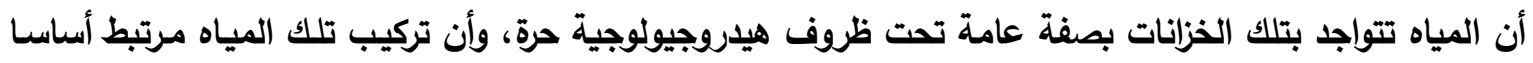

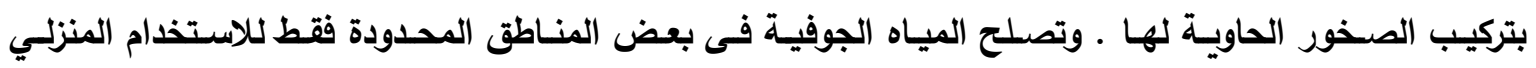

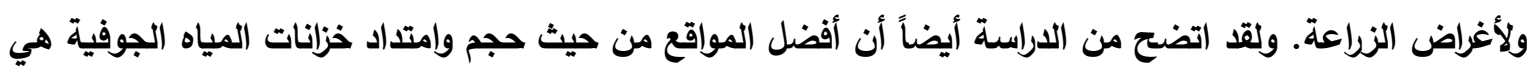

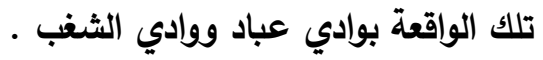

